\title{
Virulence genes in Escherichia coli isolates from commercialized saltwater mussels Mytella guyanensis (Lamarck, 1819)
}

\author{
C. A. Barbosa ${ }^{a, b *}$, T. A. Conceição ${ }^{b}$, M. D. Baliza ${ }^{b}$, V. M. A. Camilo ${ }^{b}$, P. J. L. Juiz ${ }^{c}$ and I. M. M. Silva \\ ${ }^{a}$ Centro de Ciências Agrárias Ambientais e Biológicas, Universidade Federal do Recôncavo da Bahia - UFRB, Rua Rui \\ Barbosa, 710, Centro, CEP 44380-000, Cruz das Almas, BA, Brasil \\ ${ }^{\text {b} C e n t r o ~ d e ~ C i e ̂ n c i a s ~ d a ~ S a u ́ d e, ~ C o m p l e x o ~ M u l t i d i s c i p l i n a r ~ d e ~ E s t u d o s ~ e ~ P e s q u i s a s ~ e m ~ S a u ́ d e ~-~ C O M E P S, ~ U n i v e r s i d a d e ~}$ \\ Federal do Recôncavo da Bahia - UFRB, Avenida Carlos Amaral, 1015, Cajueiro, CEP 44574-490, Santo Antônio de \\ Jesus, BA, Brasil \\ ${ }^{c}$ Centro de Ciência e Tecnologia em Energia e Sustentabilidade, Universidade Federal do Recôncavo da Bahia - UFRB, \\ Avenida Centenário, 697, Sim, CEP 44042-280, Feira de Santana, BA, Brasil \\ *e- mail: carlaalvesbarbosa@outlook.com.br
}

Received: September 29, 2017 - Accepted: February 26, 2018 - Distributed: November 30, 2019

\begin{abstract}
The isolation of Escherichia coli from food is a major concern. Pathogenic strains of these bacteria cause diseases which range from diarrhea to hemolytic-uremic syndrome. Therefore the virulence genes in $E$. coli isolates from the mussel (Mytella guyanensis) commercialized in Cachoeira, Bahia, Brazil were investigated. Samples were purchased from four vendors: two from supermarkets and two from fair outlets. They were conditioned into isothermal boxes with reusable ice and transported to the laboratory for analysis. E. coli strains were isolated in eosin methylene blue agar, preserved in brain-heart infusion medium with $15 \%$ glycerol and stored at $-20{ }^{\circ} \mathrm{C}$, after microbiological analysis. Virulence genes in the isolated strains were identified by specific primers, with Polymerase Chain Reaction. Twenty-four isolates were obtained, with a prevalence of elt gene, typical from enterotoxigenic infection, in $75 \%$ of the isolates. The stx and $b f p A$ genes, prevalent in enterohemorragic and enteropathogenic E. coli, respectively, were not detected. The occurrence of elt virulence-related gene in the E. coli isolates of Mytella guyanensis reveals urgent improvement in food processing, including good handling practices, adequate storage and cooking before consumption, to ensure consumer's health.
\end{abstract}

Keywords: bivalve mollusk, thermotolerant coliform, PCR, elt gene.

\section{Presença de genes de virulência em isolados de Escherichia coli provenientes de sururu Mytella guyanensis (Lamarck, 1819) comercializado}

\begin{abstract}
Resumo
O isolamento de Escherichia coli a partir de alimentos é uma grande preocupação, pois cepas patogênicas desta bactéria podem causar desde diarreia até síndrome hemolítico-urêmica. Diante do exposto, o objetivo do trabalho foi pesquisar genes de virulência em isolados de Escherichia coli provenientes do sururu Mytella guyanensis comercializado na cidade de Cachoeira, Bahia, Brasil. As amostras foram adquiridas de quatro comerciantes, sendo duas de mercados e duas em pontos de venda na feira livre da cidade de Cachoeira, acondicionadas em caixas isotérmicas com gelo reutilizável e transportadas até o laboratório para a análise. Após a análise microbiológica, as cepas de Escherichia coli foram isoladas em ágar Eosina Azul de Metileno e preservadas em caldo Brian Heart Infusion e glicerol a 15\% e mantidas a $-20^{\circ} \mathrm{C}$. A identificação dos genes de virulência nas cepas isoladas foi realizada utilizando primers específicos, por meio da Reação em Cadeia da Polimerase. Foram obtidos 24 isolados de Escherichia coli, destes a prevalência do gene elt, característico de Escherichia coli enterotoxigênica, foi de $75 \%$ dos isolados. Não houve a detecção dos genes stx e $b f p A$ nos isolados, os quais são prevalentes nas cepas de Escherichia coli enterohemorrágica e Escherichia coli enteropatogênica, respectivamente. A presença do gene elt relacionado à virulência de Escherichia coli nos isolados de Mytella guyanensis revela a necessidade da melhoria no processamento, incluindo boas práticas de manipulação, armazenamento adequado e cocção previa ao consumo, visando a garantia da saúde do consumidor.
\end{abstract}

Palavras-chave: molusco bivalve, coliforme termotolerante, PCR, Gene elt.

\section{Introduction}

Escherichia coli may be a commensal bacterium or it may cause several infections in humans and animals (Backer, 2015). E. coli strains which cause intestine infections are called diarrheagenic, with six pathotypes: enterohemorrhagic E. coli (EHEC); enteropathogenic E. coli (EPEC); enterotoxigenic E. coli (ETEC); enteroinvasive 
E. coli (EIEC); enteroaggregative $E$. coli (EAEC); diffused adherence $E$. coli (DAEC) (Croxen and Finlay, 2010).

Bacteria have different virulence factors to trigger infection, such as toxins and cell-adhesive mechanisms (Croxen and Finlay, 2010; Chandra et al., 2013). Highlighted toxins comprise Shiga (STX), produced by EHEC (Obrig, 2010) and codified by gene stx (Mauro and Koudelka, 2011); thermo-labile (LT) and thermo-stable (ST) toxins, produced by ETEC (Begum et al., 2014) and codified respectively by genes elt and est (Manzoor et al., 2015); and bacteria's cell-adherence mechanisms associated with EPEC (Mainil and Daube, 2005), such as bundle-forming pilus (BFP), type IV, with main structural subunit codified by gene $b f p A$ (Contreras et al., 2010; Teixeira et al., 2015).

Due to the harm done by pathogenic strains of E. coli, there is great concern with regard to strains of the microorganism in food, such as fish (Costa, 2013). According to Zhao et al. (2014), there is a high occurrence of diseases in developing countries caused by the consumption of contaminated food. The detection of contaminating agents is an important step for the development of prophylactic strategies. Polymerase Chain Reaction (PCR) is a commonly used method to detect human pathogens transmitted by the consumption of contaminated food. This highly sensitive technique is based on the amplification of specific regions of the DNA by specific primers.

Studies on the genotype characterization of bacterial isolates in commercialized mussels Mytella guyanensis are scarce, so this work aims to investigate virulence genes in E. coli isolates from the mussel (M. guyanensis) commercialized in the town of Cachoeira, Bahia, Brazil.

\section{Material and Methods}

\subsection{Sampling}

Samples of $M$. guyanensis were obtained from four sellers in the town of Cachoeira, Bahia, Brazil: two kilos of mussels were bought from two open stall outlets ( $1 \mathrm{k}$ each) and two kilos from supermarkets (1k each), between December 2015 and January 2016. Samples were conditioned in new plastic bags, identified and transported under refrigeration to the laboratory of the Research Nucleus in Food Safety and Nutrition of the Center of Health Sciences of the Federal University of Recôncavo of Bahia, in the town of Santo Antônio de Jesus, and immediately analyzed.

\subsection{Isolation and purification of strains}

E. coli populations were estimated by Petrifilm ${ }^{\mathrm{TM}}(3 \mathrm{M})$ rapid counting method, with EC plates (AOAC 998.08). An amount of each sample $(25 \mathrm{~g})$ were added to a $225 \mathrm{~mL}$ of $0.9 \% \mathrm{NaCl}$ saline solution homogenized in a stomacher for 30 seconds and diluted in series $\left(10^{-2}\right.$ and $\left.10^{-3}\right)$. About $1 \mathrm{~mL}$ of the samples were placed on plates and incubated at $35 \pm 1{ }^{\circ} \mathrm{C}$ for $24 \pm 2 \mathrm{~h}$ (Silva et al., 2007). Characteristical E. coli colonies (blue with gas bubbles) were removed by a platinum spatula, sprinkled with Eosin Methylene Blue agar (EMB) Kasvi ${ }^{\circledR}$ and incubated at $35 \pm 1^{\circ} \mathrm{C}$ for $24 \pm 2 \mathrm{~h}$. A characteristic colony (black with brilliant metallic blue), isolated from each plate, was transferred to Brain Heart Infusion (BHI) broth $\mathrm{Kasvi}^{\circledR}$ and incubated at $35 \pm 1{ }^{\circ} \mathrm{C}$ for $24 \pm 2 \mathrm{~h}$ (Silva et al., 2007). Twenty-four isolates were kept by adding glycerol $15 \%$ and stored at $-20^{\circ} \mathrm{C}$ (Silva et al., 2011).

\subsection{DNA extraction and PCR technique}

DNA extraction and PCR technique were performed according to a methodology adapted from Silva et al. (2011). Positive controls were used as standards: strain ATCC 11105 for elt gene, strain CDC EDL 933 for stx gene and strain CDC 086:H35 for $b f p A$ gene. The standardization of the PCR tests for the genes under study was performed regarding to the amount of DNA in the reaction (data not shown) and the components used for the stx and elt genes were: milli-Q sterile water $(15.2 \mathrm{uL}), 10 X P C R$ buffer $(5 \mathrm{uL})$ in final concentration $2 \mathrm{X}, 10 \mathrm{mM}$ dNTP mix $(0.5 \mathrm{uL})$ in final concentration $0.2 \mathrm{mM}, 50 \mathrm{mM} \mathrm{MgCl} 2(1.5 \mathrm{uL})$ in final concentration $3 \mathrm{mM}$, direct initiator $(0.8 \mathrm{uL})$ in final concentration $0.8 \mathrm{pmol}$, reverse initiator $(0.8 \mathrm{uL})$ in final concentration $0.8 \mathrm{pmol}$, Taq DNA polymerase $(0.2 \mathrm{uL})$ in final concentration $2 \mathrm{U}$, DNA mold ( $1 \mathrm{uL})$. For the $b f p A$ gene the following components were used: milli-Q sterile water (16.5 uL), 10XPCR buffer $(2.5 \mathrm{uL})$ in final concentration $1 \mathrm{X}, 10 \mathrm{mM}$ dNTP mix $(0.5 \mathrm{uL})$ in final concentration $0.2 \mathrm{mM}, 50 \mathrm{mM} \mathrm{MgCl} 2(0.75 \mathrm{uL})$ in final concentration $1.5 \mathrm{mM}$, direct initiator $(1 \mathrm{uL})$ in final concentration $1 \mathrm{pmol}$, reverse initiator $(1 \mathrm{uL})$ in final concentration 1 pmol, Taq DNA polymerase $(0.2 \mathrm{uL})$ in final concentration $2 \mathrm{U}$, DNA mold ( $3 \mathrm{uL})$. The total volume of components for the amplification of each gene was $25 \mathrm{uL}$. Amplification reactions were performed in thermal cycler Amplitherm ${ }^{\circledR}$ TX96 Plus, according to conditions in Table 1. PCR amplified products were loaded in a $2 \%$ agarose gel and placed in a horizontal electrophoresis system to visualize bands by employing $50 \mathrm{bp}$ molecular weight as size marker. Electrophoresis run was performed in a digital source GSR ${ }^{\circledR} 200 \mathrm{STD}$ with parameters: $80 \mathrm{v}$, $80 \mathrm{~min}, 200 \mathrm{~mA}$ for genes stx and elt and $70 \mathrm{v}, 100 \mathrm{~min}$, $200 \mathrm{~mA}$ for gene $b f p A$. Loading Dye 6X Promega ${ }^{\circledR}$ plus SYBR Green Life Technologies ${ }^{\circledR}$ were used to visualize PCR products in ultraviolet Loccus L-PIX.

Table 1. Sequence of primers, size of amplified fragment and PCR conditions.

\begin{tabular}{cccc}
\hline Gene/serotype & Primer sequence 5'- 3' & $\begin{array}{c}\text { Fragment } \\
\text { size (bp) }\end{array}$ & $\begin{array}{c}\text { Anealing } \\
\left({ }^{\circ} \mathbf{C}\right)\end{array}$ \\
\hline st $x$ EHEC & TTT ACG ATA GAC TTC TCG AC CAC ATA TAA ATT ATT TCG CTC & 227 & 48 \\
elt $/$ ETEC & GGC GAC AGA TTA TAC CGT GC CCG AAT TCT GTT ATA TAT GTC & 696 & 56 \\
bfp $/$ EPEC & AAT GGT GCT TGC GCT TGC TGC GCC GCT TTA TCC AAC CTG GTA & 330 & 56 \\
\hline
\end{tabular}

Source: Silva et al. (2011) 


\section{Results}

The results revealed amplification of elt gene, typical of ETEC, in $75 \%$ of $E$. coli isolates, of which $50 \%$ were originating from mussel samples collected in supermarkets and $50 \%$ were originating from mussel samples collected in open fair stalls. No amplification of stx and $b f p A$ gene, respectively typical of EHEC and EPEC, were observed.

\section{Discussion}

Species for biomonitoring are generally good coliform accumulators (Farrapeira et al., 2010). This indicates the importance of these microorganisms as indicators of contamination, which also extends to food. The presence of $E$. coli, a thermotolerant coliform in fish, is related to their hygienic-sanitary quality, since this bacteria indicates fecal contamination (Dutta et al., 2015). Pathogenic strains of this bacteria may occur in food, as demonstrated with gene elt in this work.

Kambire et al. (2017) conducted studies to detect $E$. coli pathotypes in samples of water, sediment, fish and crabs, and pinpointed ETEC as the most prevalent pathotype in water, sediment and crab samples. According to Anand et al. (2016), ETEC is the pathotype that causes diarrhea due to the release of potent enterotoxins, one of which is codified by gene elt. Shahrokhi et al. (2011) demonstrated that the production of LT and ST in ETEC strains is similar, although some strains may produce only a single enterotoxin, that result may explain the absence of amplifications of the stx gene.

The production of LT helps in the colonization of the host's cells and also LT uses cell components to produce its toxic effect. LT interactions with the host cell produce the constitutive activation of adenylate cyclase and the production of cyclic monophosphate adenosine (AMPc). The component's intracellular elevation activates the AMPc-dependent protein cinase A. The phosphoryl chloride is dominium $\mathrm{R}$ of the regular of the transmembrane conductance of cytic fibrose. The admission of chloride and water efflux in the intestinal lumen causes aqueous diarrhea (Johnson et al., 2009; Dubreuil et al., 2016). Therefore the research of this pathotype is extremely important in commercialization of mussels in natura.

Pathogenic strains of $E$. coli are a great concern for public health authorities due to their high dissemination capacity in different sources. Food is actually an important vector of this microorganism (Croxen et al., 2013). M. guyanensis is a filtering organism and can accumulate microorganisms and substances harmful to health (Carvalho et al., 2007). This is a major risk for consumption of raw or partially cooked foods as is usually consumed M. guyanensis (Santiago et al., 2013). Since LT of ETEC is inactivated by heating to $60^{\circ} \mathrm{C}$ for $10 \mathrm{~min}$ (Takeda, 2011), the consumption of cooked food is highly relevant. According to Santos et al. (2014), treatment is a must to warrant sanitary conditions of the final product. Carvalho et al. (2016) showed that the detection of pathogenic bacteria in fish is crucial for the development of strategies that guarantee their quality for consumers and it may be extended do other marine source of food.

Genes related to $E$. coli virulence in isolates of $M$. guyanensis reveal the need of improvement during processing, including good handling practices, proper storage and cooking prior to consumption. These factors guarantee consumer's health. In fact, cooking maintains the microbiological quality of food and inactivates ETEC thermal labile toxin.

\section{Acknowledgements}

The authors would like to thank the Coordination for the Improvement of Higher Education Personnel (CAPES) for grants.

\section{References}

ANAND, S., MANDAL, S., PATIL, P. and TOMAR, S.K., 2016. Pathogen-induced secretory diarrhea and its prevention. European Journal of Clinical Microbiology \& Infectious Diseases, vol. 35, no. 11, pp. 1721-1739. http://dx.doi.org/10.1007/s10096-0162726-5. PMid:27473379.

BACKER, K.S., 2015. Demystifying Escherichia coli pathovars. Nature Reviews. Microbiology, vol. 13, no. 1, pp. 5. http://dx.doi. org/10.1038/nrmicro3411. PMId: 25482288.

BEGUM, Y.A., BABY, N.I., FARUQUE, A.S., JAHAN, N., CRAVIOTO, A., SVENNERHOLM, A.M. and QADRI, F., 2014. Shift in Phenotypic Characteristics of Enterotoxigenic Escherichia coli (ETEC) Isolated from Diarrheal Patients in Bangladesh. PLoS Neglected Tropical Diseases, vol. 8, no. 7, pp. e3031. http://dx.doi. org/10.1371/journal.pntd.0003031. PMid:25032802.

CARVALHO, A.F.U., FARIAS, D.F., BARROSO, C.X., SOMBRA, C.M.L., SILVINO, A.S., MENEZES, M.O.T., SOARES, M.O., FERNANDES, D.A.O. and GOUVEIA, S.T., 2007. Nutritive value of three organisms from mangrove ecosystem: Ucides cordatus (Linnaeus, 1763), Mytella sp. (Soot-Ryen, 1955) and Crassostrea rhizophorae (Guilding, 1828). Brazilian Journal of Biology $=$ Revista Brasileira de Biologia, vol. 67, no. 4, pp. 787-788. http://dx.doi.org/10.1590/S1519-69842007000400031. PMid:18278338.

CARVALHO, M.C.N., JAYME, M.M., ARENAZIO, G.S., ARAÚJO, F.V., LEITE, S.G.F. and DEL-AGUILA, A.M., 2016. Microbiological Quality Assessment by PCR and Its Antibiotic Susceptibility in Mangrove Crabs (Ucides cordatus) from Guanabara Bay, Rio de Janeiro. Brazililian International Journal of Microbiolology, vol. 2016, pp. 7825031. http://dx.doi. org/10.1155/2016/7825031. PMid:27065187.

CHANDRA, M., CHENG, P., RONDEAU, G., PORWOLLIK, S. and MCCLELLAND, M., 2013. A single step multiplex PCR for identification of six diarrheagenic E. coli pathotypes and Salmonella. International Journal of Medical Microbiology, vol. 303, no. 4, pp. 210-216. http://dx.doi.org/10.1016/j.ijmm.2013.02.013. PMid:23562277.

CONTRERAS, C.A., OCHOA, T.J., LACHER, D.W., DEBROY, C., NAVARRO, A., TALLEDO, M., DONNENBERG, M.S., ECKER, L., GIL, A.I., LANATA, C.F. and CLEARY, T.G., 2010. Allelic variability of critical virulence genes (eae, $b f p A$ and $\operatorname{per} A$ ) in typical and atypical enteropathogenic Escherichia coli in Peruvian children. Journal of Medical Microbiology, vol. 
59, no. 1, pp. 25-31. http://dx.doi.org/10.1099/jmm.0.013706-0. PMid:19797469.

COSTA, R.A., 2013. Escherichia coli in seafood: A brief overview. Advances in Bioscience and Biotechnology, vol. 4, no. 3A, pp. 450-454. http://dx.doi.org/10.4236/abb.2013.43A060.

CROXEN, M.A. and FINLAY, B.B., 2010. Molecular mechanisms of Escherichia coli pathogenicity. Nature Reviews. Microbiology, vol. 8, no. 1, pp. 26-38. http://dx.doi.org/10.1038/nrmicro2265. PMid:19966814.

CROXEN, M.A., LAW, R.J., SCHOLZ, R., KEENEY, K.M., WLODARSKA, M. and FINLAY, B.B., 2013. Recent Advances in Understanding Enteric Pathogenic Escherichia coli. Clinical Microbiology Reviews, vol. 26, no. 4, pp. 822-880. http://dx.doi. org/10.1128/CMR.00022-13. PMid:24092857.

DUBREUIL, J.D., ISAACSON, R.E. and SCHIFFERLI, D.M., 2016. Animal Enterotoxigenic Escherichia coli. EcoSal Plus, vol. 7, no. 1, pp. 1-47. http://dx.doi.org/10.1128/ecosalplus. ESP-0006-2016. PMid:27735786.

DUTTA, C., PANIGRAHI, A.K. and SENGUPTA, C., 2015. Prevalence of Pathogenic Bacteria in Finfish and Shellfish Obtained from Domestic Markets of West Bengal, India. Frontiers in Environmental Microbiology, vol. 1, no. 2, pp. 14-18. http:// dx.doi.org/10.11648/j.fem.20150102.11.

FARRAPEIRA, C.M.R., MENDES, E.S., DOURADO, J. and GUIMARÃES, J., 2010. Coliform accumulation in Amphibalanus amphitrite (Darwin, 1854) (Cirripedia) and its use as an organic pollution bioindicator in the estuarine area of Recife, Pernambuco, Brazil. Brazilian Journal of Biology $=$ Revista Brasileira de Biologia, vol. 70, no. 2, pp. 301-309. http://dx.doi.org/10.1590/ S1519-69842010000200011. PMid:20549061.

JOHNSON, A.M., KAUSHIK, R.S., FRANCIS, D.H., FLECKENSTEIN, J.M. and HARDWIDGE, P.R., 2009. Heat-Labile Enterotoxin Promotes Escherichia coli Adherence to Intestinal Epithelial Cells. Journal of Bacteriology, vol. 191, no. 1, pp. 178-186. http://dx.doi.org/10.1128/JB.00822-08. PMid:18978047.

KAMBIRE, M.A., ADINGRA, A.A., YAO, K.M. and KOFFINEVRY, R., 2017. Prevalence of Virulence Genes Associated with Diarrheagenic Pathotypes of Escherichia coli Isolates from Water, Sediment, Fish, and Crab in Aby Lagoon, Côte d'Ivoire. International Journal of Microbiology, vol. 2017, no. 2017, pp. 9532170. https://doi.org/10.1155/2017/9532170. PMId: 28676828.

MAINIL, J.G. and DAUBE, G., 2005. Escherichia coli from animals, humans and foods: who's who? Journal of Applied Microbiology, vol. 98 , no. 6, pp. 1332-1344. http://dx.doi.org/10.1111/j.13652672.2005.02653.x. PMid:15916647.

MANZOOR, R., SHAH, M.I., UL-HUSNA, A., WANI, S.A., PANDIT, F., DAR, P.A. and MIR, M.I., 2015. Prevalence, serodiversity and antibiogram of enterotoxigenic Escherichia coli (ETEC) in diarrhoeic calves and lambs of Kashmir valley (J\&K),
India. Journal of Applied and Natural Science, vol. 7, no. 1, pp. 477-481. http://dx.doi.org/10.31018/jans.v7i1.635.

MAURO, S.A. and KOUDELKA, G.B., 2011. Shiga Toxin: Expression, Distribution, and Its Role in the Environment. Toxins, vol. 3, no. 6, pp. 608-625. http://dx.doi.org/10.3390/ toxins3060608. PMid:22069728.

OBRIG, T.G., 2010. Escherichia coli Shiga Toxin Mechanisms of Action in Renal Disease. Toxins, vol. 2, no. 12, pp. 2769-2794. http://dx.doi.org/10.3390/toxins2122769. PMid:21297888.

SANTIAGO, J.A.S., ARAÚJO, P.F.R., SANTIAGO, A.P., CARVALHO, F.C.T. and VIEIRA, R.H.S.F., 2013. Bactérias patogênicas relacionadas a ingestão de pescados - revisão. Arquivos de Ciências do Mar, vol. 46, no. 2, pp. 92-103.

SANTOS, T.M.M., SAWAYA, A.L., SILVA, M.C.D., SANTOS, A.F., BARROS-NETO, J.A. and FLORÊNCIO, T.M.M.T., 2014. Avaliação microbiológica e da concentração de vitamina A, ferro e zinco em preparações do molusco sururu (Mytella falcata). Demetra Alimentação. Nutrição \& Saúde, vol. 9, no. 3, pp. 811-822.

SHAHROKHI, N., BOUZARI, S. and JAFARI, A., 2011. Comparison of virulence markers and antibiotic resistance in enterotoxigenic Escherichia coli isolated ten years apart in Tehran. Journal of Infection in Developing Countries, vol. 5, no. 4, pp. 248-254. PMid:21537065.

SILVA, I.M.M., EVÊNCIO-NETO, J., SILVA, R.M., LUCENASILVA, N., MAGALHÃES, J. and BALIZA, M., 2011. Caracterização genotípica dos isolados de Escherichia coli provenientes de frangos de corte. Arquivo Brasileiro de Medicina Veterinária e Zootecnia, vol. 63, no. 2, pp. 333-339. http://dx.doi.org/10.1590/ S0102-09352011000200010.

SILVA, N., JUNQUEIRA, V.C.A., SILVEIRA, N.F.A., TANIWAKI, M.H., SANTOS, R.F.S. and GOMES, R.A.R., 2007. Manual de métodos de análise microbiológica de alimentos e água. 3. ed. São Paulo: Varela, 544 p.

TAKEDA, Y., 2011. Vibrio parahaemolyticus, enterotoxigenic Escherichia coli, enterohemorrhagic Escherichia coli and Vibrio cholerae. Proceedings of the Japan Academy. Series B, Physical and Biological Sciences, vol. 87, no. 1, pp. 1-12. http://dx.doi. org/10.2183/pjab.87.1. PMid:21233598.

TEIXEIRA, N.B., ROJAS, T.C., SILVEIRA, W.D., MATHEUSGUIMARÃES, C., SILVA, N.P. and SCALETSKY, I.C., 2015. Genetic analysis of enteropathogenic Escherichia coli (EPEC) adherence factor (EAF) plasmid reveals a new deletion within the EAF probe sequence among O119 typical EPEC strains. $B M C$ Microbiology, vol. 15, no. 1, pp. 200. http://dx.doi.org/10.1186/ s12866-015-0539-9. PMid:26438110.

ZHAO, X., LIN, C.W., WANG, J. and OH, D.H., 2014. Advances in Rapid Detection Methods for Foodborne Pathogens. Journal of Microbiology and Biotechnology, vol. 24, no. 3, pp. 297-312. http://dx.doi.org/10.4014/jmb.1310.10013. PMid:24375418. 